\title{
Pseudione tuberculata Richardson, 1904 (Isopoda: Bopyridae): a parasite of juveniles of the king crab Lithodes santolla (Molina, 1782) (Anomura: Lithodidae) in the Magellan Strait, Chile
}

\author{
Pseudione tuberculata Richardson, 1904 (Isopoda: Bopyridae): un parásito de juveniles de centolla \\ Lithodes santolla (Molina, 1782) (Anomura: Lithodidae) en el estrecho de Magallanes, Chile \\ Juan I. Cañete ${ }^{1}$, César A. Cárdenas ${ }^{1,2}$, Sylvia Oyarzún ${ }^{1}$ Jordi Plana², \\ Mauricio Palacios ${ }^{3}$ and Mario Santana ${ }^{1}$ \\ ${ }^{1}$ Departamento de Ciencias y Recursos Naturales, Facultad de Ciencias, Universidad de Magallanes, \\ Casilla 113-D, Punta Arenas, Chile \\ ${ }^{2}$ Programa Magíster en Ciencias, Mención Manejo y Conservación de Recursos Naturales en Ambientes \\ Subantárticos, Facultad de Ciencias, Universidad de Magallanes, Punta Arenas, Chile \\ ${ }^{3}$ Laboratorio Centro de Investigación para la Acuicultura y Recursos Marinos Subantárticos, \\ Facultad de Ciencias, Universidad de Magallanes, Punta Arenas, Chile \\ ivan.canete@umag.cl
}

\begin{abstract}
Resumen.- El isópodo parásito Pseudione tuberculata Richardson, 1904 infesta la cavidad branquial de especies de la familia Lithodidae en el extremo sur de Sudamérica. Ha sido descrito previamente como parásito de Neolithodes en el Archipiélago de los Chonos, Chile, y en Paralomis granulosa (Jacquinot, 1847) y Lithodes santolla (Molina, 1782) en aguas someras del canal Beagle, Argentina. Es la primera vez que el parásito es documentado en Chile en el estrecho de Magallanes, ubicado alrededor de $640 \mathrm{~km}$ al norte del canal Beagle, parasitando juveniles de L santolla (23,0 a 51,6 mm LC en hembras y entre 24,0 a $48,7 \mathrm{~mm}$ en machos). La frecuencia del parásito en centollas fue de $27,97 \%$ en hembras y $21,43 \%$ en machos. La frecuencia de infestación fue mayor a la descrita en otros crustáceos chilenos parasitados por Pseudione. Cada centolla portaba una pareja de $P$. tuberculata dentro de la cavidad branquial en el lado izquierdo del caparazón. Las altas tasas de parasitismo de $P$. tuberculata en centollas juveniles en el área podría ocurrir en aguas someras habitadas por Macrocystis pyrifera debido a su efecto en las condiciones hidrodinámicas locales, la reducción del flujo y la amortiguación del oleaje, proporcionando hábitats para diversos organismos marinos. Se concluye que $P$. tuberculata como parásito de L. santolla, en el estrecho de Magallanes, responde de manera similar al compararse con los valores de infestación de estudios previos desarrollados en el canal Beagle, Argentina, en donde ha sido reportada infestando $P$. granulosa y $L$. santolla.
\end{abstract}

Palabras clave: Bentos subantártico, litódidos, parasitismo, bopíridos, región magallánica

\begin{abstract}
The parasitic bopyrid isopod Pseudione tuberculata Richardson, 1904 infests the branchial chamber of species of the family Lithodidae found along the southern tip of South America. It was previously known only as a parasite of Neolithodes off the Chonos Archipelago, Chile, as well as Paralomis granulosa (Jacquinot, 1847) and Lithodes santolla (Molina, 1782) from shallow waters of the Beagle Channel, Argentina. This is the first time the parasite is documented in Chile at the Magellan Strait, located about $640 \mathrm{~km}$ north of the Beagle Channel, infesting mainly on juveniles of $L$. santolla (23.0 to $51.6 \mathrm{~mm}$ CL in females and from 24.0 to $48.7 \mathrm{~mm}$ in males). Prevalence of the parasite in crabs was $27.9 \%$ in females and $21.4 \%$ in males. Prevalence was higher than those reported in other Chilean crustaceans parasitized by other Pseudione species. Each king crab carried a single pair of $P$. tuberculata within the branchial chamber on the left side of the carapace. High rates of parasitism of $P$. tuberculata on juvenile king crabs in this area could occur in shallow water inhabited by Macrocystis pyrifera kelp due to the plant's effect on the local hydrodynamic conditions, reducing flow and damping waves, providing habitats for several organisms. It is concluded that $P$. tuberculata infesting $L$. santolla at the Magellan strait responds in a similar way when compared with prevalence values from previous studies developed at the Beagle Channel, Argentina, where it has been reported infesting $P$. granulosa and L. santolla.
\end{abstract}

Key words: Subantarctic benthos, lithodids, parasitism, bopyrids, Magellan region

\section{Introduction}

Bopyrid isopods are ectoparasites that can cause sterilization or reduce gametogenesis, and modify the external characters in the definitive host. Bopyrids have three larval stages, the first stage, the epicardium lives attached to a calanoid copepod, where it develops into the microniscus larval stage. Upon reaching the following cryptoniscus stage, the individual leaves the intermediate 
host and attaches to the definitive host, usually a decapod crustacean (Beck 1980). The first cryptoniscus larva infesting the definitive host develops into a female, while the next to arrive develops into a dwarf male, which remains attached to the female (Anderson 1990).

Infestation by bopyrid parasites has been frequently observed in species of several decapod infraorders, including thalassinideans, brachyurans, anomurans (Dall et al. 1990, Thatje 2003). The genus Pseudione has the most described species. According to Miranda-Vargas \& Roccatagliata (2004), five species in this genus have been described from the southern part of South America (ChileArgentina) including: Pseudione brattstroemi Stuardo et al., 1986, parasitic on the ghost shrimp Neotrypaea uncinata (H. Milne-Edwards, 1837); Pseudione humboldtensis Pardo et al. 1998, parasitic on the squat lobsters Cervimunida johni Porter, 1903 and Pleuroncodes monodon (H. Milne-Edwards, 1837); and Pseudione chiloensis Román-Contreras \& Werthmann, 1997, parasitic on the hippolytid shrimp Nauticaris magellanica (A. Milne-Edwards, 1891) (Stuardo et al. 1986, Román-Contreras \& Werthmann, 1997, Pardo et al. 1998). Recently, Miranda-Vargas \& Roccatagliata (2004) re-described P. tuberculata, originally described by Richardson (1904), as a parasite on the king crab Neolithodes diomedeae from the Chonos Archipelago in southern Chile. Several studies analyzed the parasitic relationships of this species in Argentina. Vinuesa (1989) reported an unidentified bopyrid infesting Paralomis granulosa (Jacquinot, 1847) and Lithodes santolla (Molina, 1782) in the Beagle Channel. Lovrich (1991) analyzed additional material of $P$. granulosa-bearing bopyrids. More recently, Roccatagliata \& Lovrich (1999) carried out an intense sampling program in the study of the association between $P$. granulosa and P. tuberculata, and later, Miranda-Vargas \& Roccatagliata (2004) presented a re-description and reported a new host for the parasitic bopyrid isopod Pseudione tuberculata on 17 females and 16 males of the king crab Lithodes santolla. Nevertheless, no information on the infestation percentage and prevalence by sex of host were mentioned in the above-cited studies.

During a study to describe the recruitment cycle of Southern king crab Lithodes santolla in the kelp beds of Macrocystis pyrifera located in two shallow, sandy-rocky embayments at less than $10 \mathrm{~m}$ in depth in the Magellan Strait, Chile, we discovered juvenile king crabs with the left side of their carapace inflated in the region of the branchial chamber. One large female parasite identified as Pseudione tuberculata Richardson, 1904 was observed inside the crab's branchial cavity.
In spite of the economic importance of $L$. santolla and an extensive history of research on the exploited portion of this population, few studies have been published on its early benthic stages (Lovrich 1997, Tapella \& Lovrich 2006, Cárdenas et al. 2007). The present study reports for the first time, the presence of the parasitic isopod P. tuberculata in the king crab Lithodes santolla in Chilean waters, as well as data on the parasitic relationship between $P$. tuberculata and $L$. santolla juveniles in the Magellan Strait, Chile.

\section{Material and methods}

\section{Study area}

San Juan Bay ( $53^{\circ} 38^{\prime}$ S, $70^{\circ} 56^{\prime}$ W), is shallow, with a sandy bottom typically less than $10 \mathrm{~m}$ in depth over most of its area, located on the eastern coast of Brunswick Peninsula, Magellan Strait (Fig. 1). There is a small section of subtidal rocky bottom at its northeastern end. The San Juan River delivers freshwater into this bay, with an average flow of $18.02 \mathrm{~m}^{3} \mathrm{~s}^{-1}$, causing a decrease in salinity. The flow of freshwater into the bay is reduced during the summer (6.3 to $9.4 \mathrm{~m}^{3} \mathrm{~s}^{-1}$ ) and attains maximum values of 29.0 to $32.7 \mathrm{~m}^{3}$ $\mathrm{s}^{-1}$ of during the spring (September - October). The second site was Steamer Bay (53³6’S; 7055’W), located 1 km north to San Juan Bay. It is a small coastal indentation, measuring only about $400 \mathrm{~m}$ in length and $150 \mathrm{~m}$ wide, with an average depth of $5 \mathrm{~m}$. The zone closest to the coastline is surrounded by a band of rocks and boulders, changing with depth to shelly sands. A kelp bed consisting of Macrocystis pyrifera occupies the bottom in a band parallel to the coast from depths of 3 to $5 \mathrm{~m}$ (Cárdenas et al. 2007).

\section{Collection of $L$. santolla juvenile}

Samples of $L$. santolla juvenile were collected by SCUBA diving from a boat between 1-8 $\mathrm{m}$ depth at Punta Santa

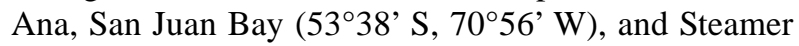
Bay (53³6’'S; 7055’W), Magellan Strait, Chile (Fig. 1) in October-November, 2005 and September 2006, during a total diving time of about $4 \mathrm{~h}$ over an area of about 200 to $300 \mathrm{~m}^{2}$ in Macrocystis pyrifera beds. Crabs were found associated with $M$. pyrifera holdfasts under the sporophylls and fronds in contact with the bottom; in some cases, the crabs were found under stones of about 30 to $60 \mathrm{~cm}$ in diameter. Profiles of temperature, salinity and density were recorded with a Sea Bird Electronics 19-3 CTD device at each sampling station.

All specimens of $L$. santolla sampled were measured and examined by stretching the lateral swelling of the carapace from the body in order to determinate whether the parasite was present following the procedure 

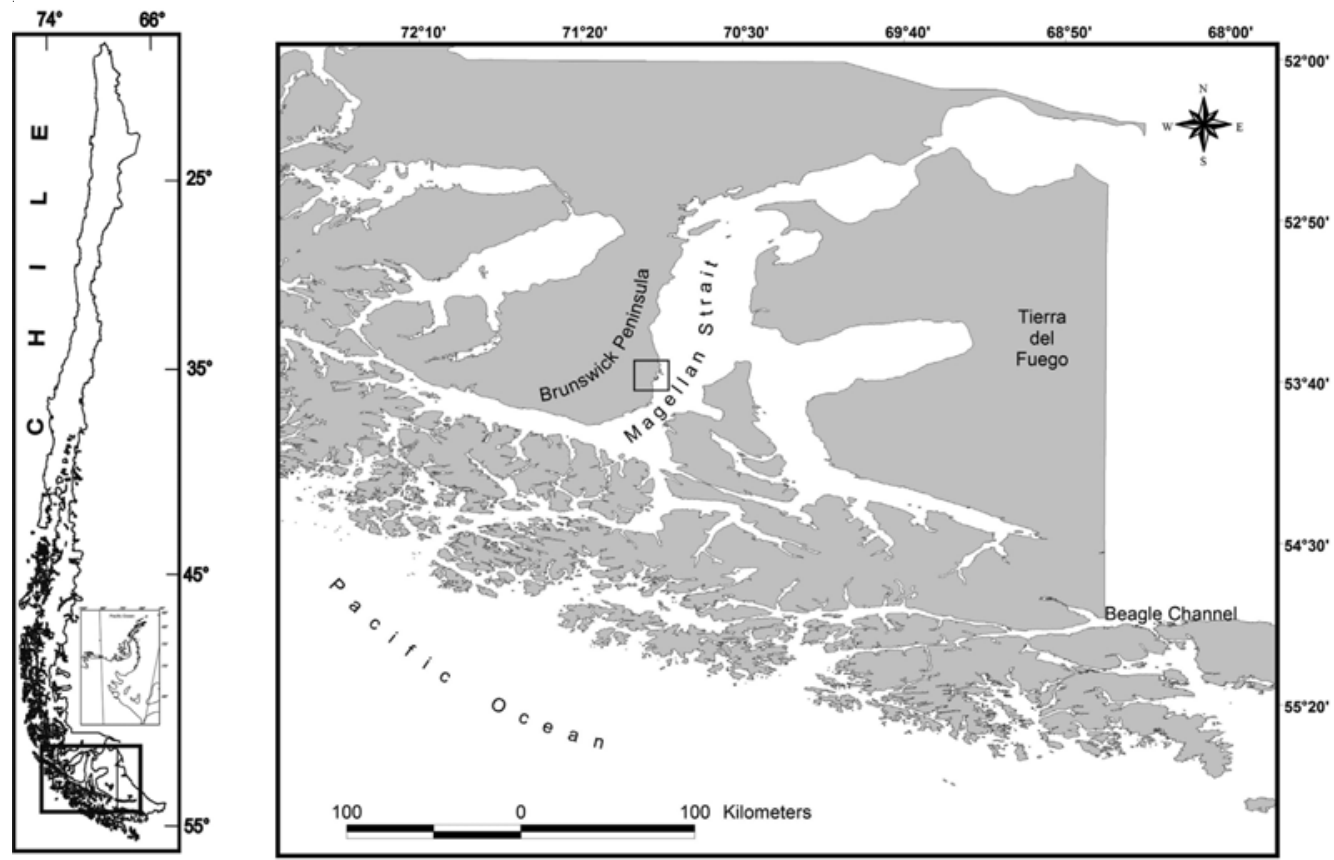

Figure 1

Geographic location of the study area in the Magellan region, Chile

Ubicación geográfica del área de estudio en la región Magallánica, Chile

proposed by Roccatagliata \& Lovrich (1999). The carapace length (CL) of each crab was measured from the posterior edge of the basis of the rostrum to the centre of the posterior edge of the carapace, as commonly used in this species (Roccatagliata \& Lovrich 1999, Lovrich et al. 2004, Cárdenas et al. 2007). Growth models provided by Campodónico et al. (1974) and Lovrich (1997) were use to assess the size/age relationship of the specimens. The infested juvenile were dissected to extract bopyrids by removal of the left side of the branchial chamber. $P$. tuberculata tends to occur on the left side of the branchial chamber of their host as described by Roccatagliata \& Lovrich (1999) and Miranda-Vargas \& Roccatagliata (2004). The wet weights of all the juvenile king crabs collected were determined with a precision of $\pm 0.1 \mathrm{~g}$. The body length of each Pseudione was measured using an ocular micrometer in a stereo microscope. The length of the females was measured from the anterior margin of the cephalon to the anterior margin of pleotelson. Males were measured from the anterior margin of cephalon to the posterior margin of pleotelson.

\section{Taxonomic identification}

Taxonomic identification was made following the literature on Pseudione spp., including Benedict (1894), Stuardo et al. (1986), Pardo et al. (1998), Román-Contreras \&
Werthmann (1997) and Miranda-Vargas \& Roccatagliata (2004). A confirmation of the identity of Pseudione tuberculata was made by Dr. Daniel Roccatagliata of the Universidad de Buenos Aires, Argentina.

The diagnostic characters used in the identification included: body oval in shape, almost or all symmetrical, coxal plates not visible in dorsal view, the pleonal lateral plates and pleopods are moderately developed and the uropods are uniramous; uropods covered by pleopods; epimera of pleomeres slightly less produced; first oostegite, postero-lateral projection extending almost straight back; tubercules on marsupium; pleopods in all specimens barely extending beyond sides of pleon, and leaving mid-ventral surface of pleon exposed (marsupial female).

Voucher specimens of $P$. tuberculata (3 males/3 females) were deposited at the Museo Argentino de Ciencias Naturales in Buenos Aires, Argentina (MACN36.692).

\section{Data analysis}

An analysis of variance (ANOVA) was used to determine significant differences in prevalence of infestation between males and females of Lithodes santolla, using Statistica 7.0 computer software. When significant differences were found, a posteriori Newman-Keuls test 
was applied to the data (Zar 1999). All our conclusions were based on a 95\% $(P<0.05)$ confidence level.

\section{Results}

\section{Levels of infestation}

A total of 216 L. santolla juvenile were collected at the Magellan Strait site. Sizes of the crabs ranged from 20.069.0 mm CL for females and from 18.5-75.0 mm CL for males. Overall, 54 (25.0\%) of the L santolla juveniles analyzed were infested by Pseudione tuberculata. Of the 118 females examined, 33 were infested by P. tuberculata (27.9\%), while of 98 males, 21 (21.4\%) were infested. No significant differences were found between sexes in relation to possible effects of $P$. tuberculata on the crab size $(P=0.991)$ and weight $(P=0.107)$. In all cases infestation consisted of one pair of bopyrids (adult female with a dwarf adult male) (Fig. 2). No multiple infestations were observed. P. tuberculata was always found on the left side of the carapace of the host (Fig. 3), with the exception of one case, in which a juvenile king crab was infested on the right side. In one case a juvenile was infested by P. tuberculata and also by the rhizocephalan Briarosaccus callosus, a rhizocephalan commonly reported infesting lithodids crabs (Lovrich et al. 2004). This is the first time P. tuberculata is reported infesting $L$. santolla in Chile.

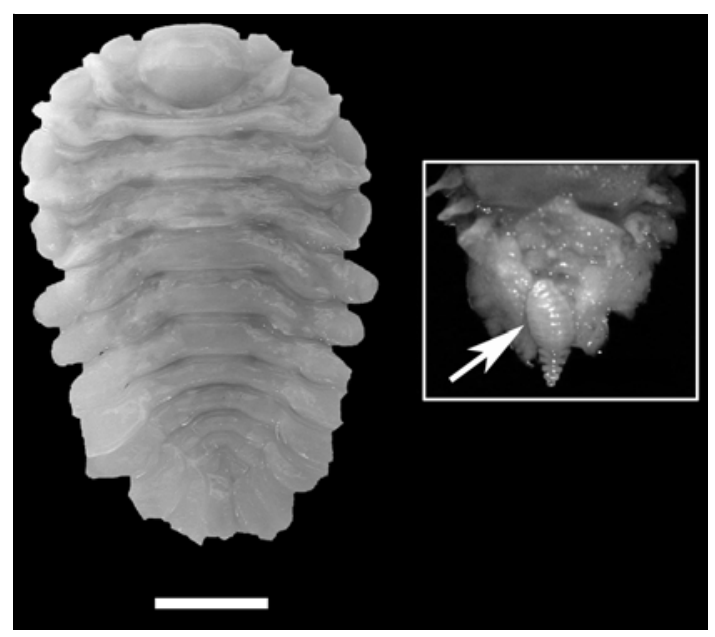

Figure 2

Dorsal view of adult female of the bopyrid isopod Pseudione tuberculata collected in the Magellan Strait, Chile, parasitic on the king crab Lithodes santolla. The small square depicts the ventral posterior end of an adult female and the dwarf adult male (white arrow). Scale (both figures) $=0.5 \mathrm{~mm}$

Vista dorsal de hembra adulta del isópodo bopírido Pseudione tuberculata recolectada en el estrecho de Magallanes, Chile, parásito de la centolla Lithodes santolla. El cuadrado pequeño retrata el extremo posterior ventral de una hembra adulta y la ubicación del macho adulto enano (flecha blanca). Escala (ambas figuras) $=0,5 \mathrm{~mm}$

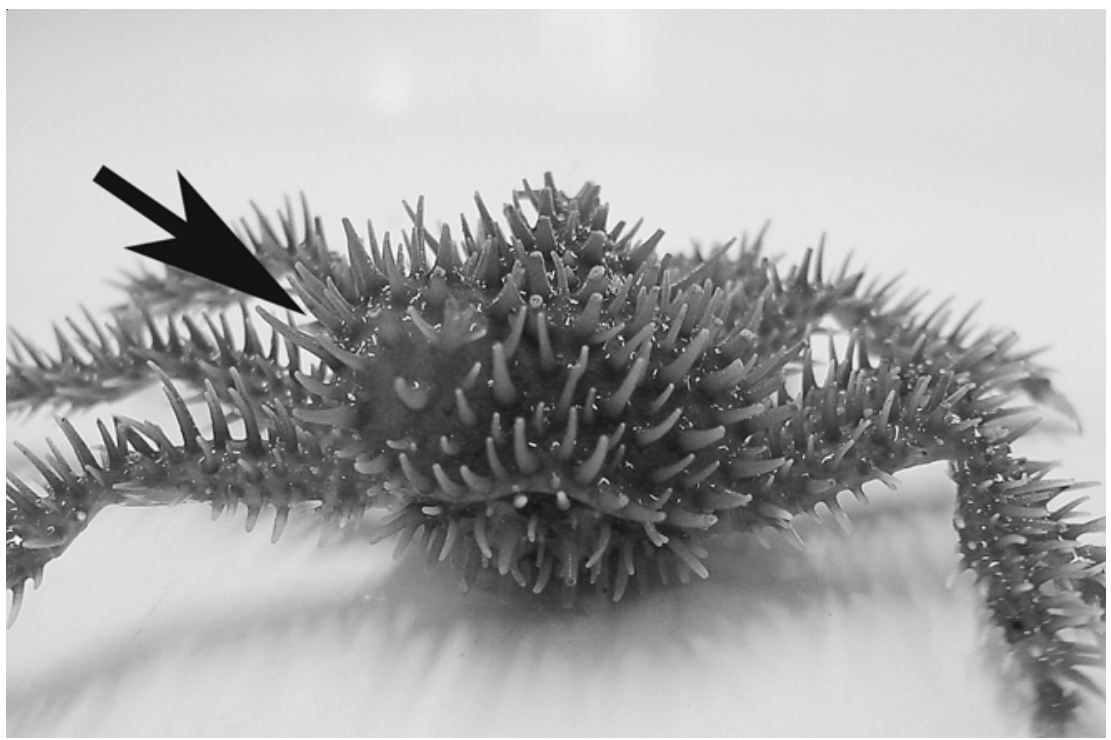

Figure 3

Posterior end of the Lithodes santolla juvenile with the left side inflated by the presence of the bopyrid parasite Pseudione tuberculata (black arrow). Carapace length of this specimen $=26 \mathbf{m m}$

Extremo posterior de un juvenil de Lithodes santolla con el lado izquierdo del caparazón inflado por la presencia de bopírido parásito Pseudione tuberculata (flecha negra). Longitud del caparazón del especimen = $26 \mathrm{~mm}$ 


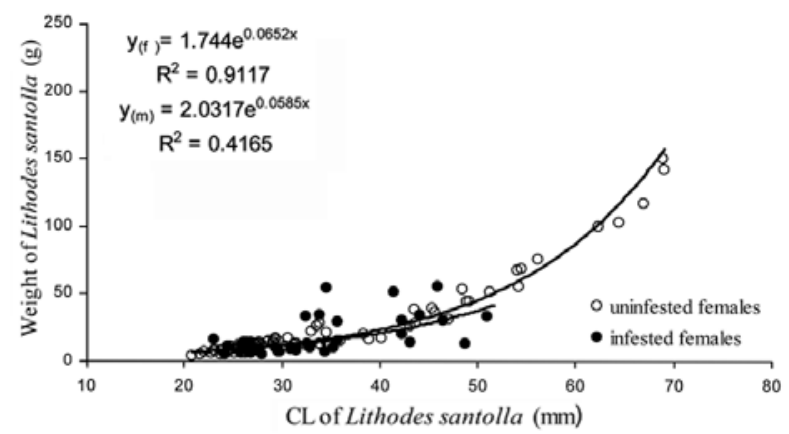

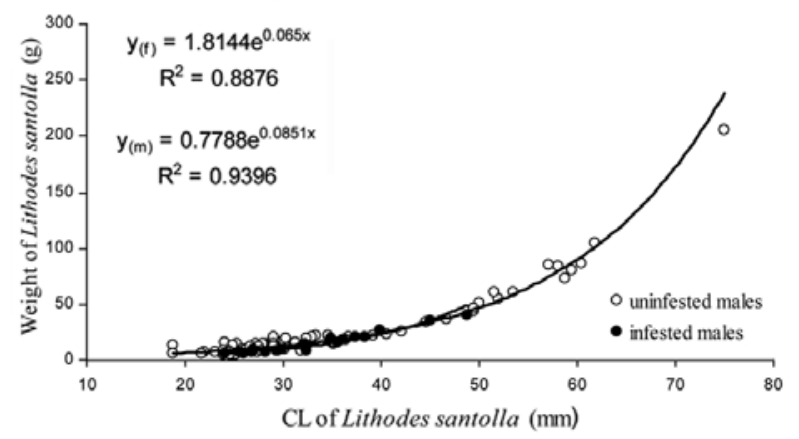

Figure 4

Length-weight relationship of Lithodes santolla uninfested and infested with the bopyrid isopod Pseudione tuberculata from the Magellan Strait, Chile. $\mathbf{N}$ (females) $=118 ; \mathbf{N}$ (males) $=98$

Relación longitud-peso de Lithodes santolla no infectadas e infectadas con el isópodo bopírido Pseudione tuberculata en el estrecho de Magallanes, Chile. $\mathrm{N}($ hembras $)=118 ; \mathrm{N}$ (machos) $=98$

Sizes of infested female crabs ranged from 23.0 to 51.6 $\mathrm{mm}$ CL, while male infested crabs ranged from 24.0 to 48.7 $\mathrm{mm}$ CL. The length-weight relationship between the infested and uninfested male and female crabs is shown in Fig. 4. No infested crabs of either sex were larger than $51.6 \mathrm{~mm}$ CL. No significant differences in the length-weight relationship were observed between males ( $P=0.684$; $P=0.165)$ and females $(P=0.755 ; P=0.352)$. Weight of infested females ranged from 4.8 to $55.9 \mathrm{~g}$, while the males weighed from 6.2 to $39.7 \mathrm{~g}$. No significant differences were found between length and weight of parasitized and unparasitized juveniles ( $P=0.0991 ; P=0.107)$.

The average length of the parasite was $13.9 \pm 2.2 \mathrm{~mm}$ $(\mathrm{N}=32)$. The average total weight of each parasite pair was $0.61 \pm 0.45 \mathrm{~g}(\mathrm{~N}=32)$ in the crab females and was $0.49 \pm 0.34 \mathrm{~g}(\mathrm{~N}=20)$ in males. The average weight of parasitized crab females was $19.2 \pm 14.9 \mathrm{~g}(\mathrm{~N}=33)$, while in males it was $15.1 \mathrm{~g} \pm 9.7 \mathrm{~g}(\mathrm{~N}=20)$. The average weight of unparasitized crab females was $24.31 \mathrm{~g} \pm 29.27$ $\mathrm{g}(\mathrm{N}=85)$, while in males was $24.8 \mathrm{~g} \pm 30.5(\mathrm{~N}=77)$.

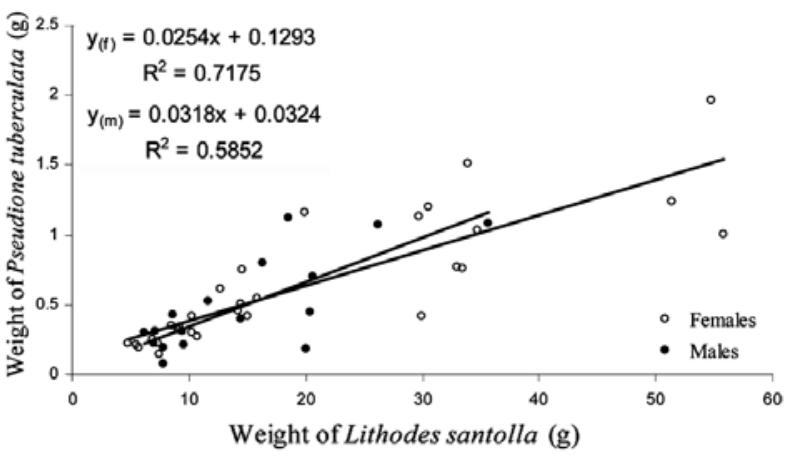

Figure 5

Relationship between weight of Lithodes santolla and weight of Pseudione tuberculata from the Magellan Strait, Chile. $\mathbf{N}$ (females) = 32; $\mathbf{N}$ (males) $=17$

Relación entre el peso de Lithodes santolla y el peso de Pseudione tuberculata en el estrecho de Magallanes, Chile. $\mathrm{N}$ (hembras) = 32; $\mathrm{N}$ (machos) $=17$

\section{Total weight of king crab and total weight of Pseudione tuberculata}

The relationship between the total weight of $L$. santolla recruits and the combined weight of each pair of $P$. tuberculata (male + female) was analysed (Fig. 5). A linear relationship was observed between both parameters, where the male crabs that were 10 to $20 \mathrm{~g}$ had parasites of larger sizes than the female crabs. It also showed that the regression curves for both sexes had a determination coefficient $\left(\mathrm{R}^{2}\right)$ of above $58 \%$. With the increasing size of Lithodes both regression lines show higher differences. Table 1 shows size and weight values for the king crab Lithodes santolla and the parasitic bopyrid isopod Pseudione tuberculata.

\section{Discussion}

The presence of $P$. tuberculata in the branchial chamber of juvenile $L$. santolla analyzed in this paper was reported earlier by Richardson (1904) on Neolithodes diomedeae in the Chonos Archipelago, Chile. Later, Stuardo et al. (1986), Román-Contreras \& Werthmann (1997) and Pardo et al. (1998) reported the presence of another member of the isopod genus in other benthic crustaceans of the Chilean coast. Recently, Miranda-Vargas \& Roccatagliata (2004) re-described P. tuberculata and cited the presence of this parasite in the lithodids Paralomis granulosa and L. santolla in the Beagle Channel, Argentina.

The present study is the first report of $P$. tuberculata infecting $L$. santolla in Chile, with a new location at the Magellan Strait, about $640 \mathrm{~km}$ north of the Beagle Channel 
Table 1

\section{Size and weight values for the king crab Lithodes santolla and the parasitic bopyrid isopod Pseudione tuberculata in the Magellan Strait, Chile. Wet weight of Pseudione represents male-female pair. $\mathbf{N}=33$ parasitized female crabs and 20 male crabs. All females were found without eggs}

Valores de talla y peso para la centolla Lithodes santolla y el isópodo bopírido Pseudione tuberculata en el estrecho de Magallanes, Chile. El peso húmedo de Pseudione representa al par macho-hembra. $\mathrm{N}=33$ centollas hembras parasitadas y 20 centollas machos parasitados. Todas las hembras fueron encontradas sin huevos

\begin{tabular}{lcccc}
\hline Sex & $\begin{array}{c}\text { Carapace length } \\
(\mathrm{mm})\end{array}$ & $\begin{array}{c}\text { Weight of king crab } \\
(\mathrm{g})\end{array}$ & $\begin{array}{c}\text { Length of } P . \\
\text { tuberculata }(\mathrm{mm})\end{array}$ & $\begin{array}{c}\text { Weight of } P . \\
\text { tuberculata }(\mathrm{g})\end{array}$ \\
\hline Female average $\pm \mathrm{SD}$ & $34.5 \pm 8.4$ & $19.2 \pm 14.9$ & $15.5 \pm 3.2$ & $0.61 \pm 0.45$ \\
Range & $23.0-51.6$ & $4.8-55.9$ & $10.0-21.8$ & $0.12-1.96$ \\
Male Average $\pm \mathrm{SD}$ & $32.9 \pm 6.6$ & $15.1 \pm 9.7$ & $15.5 \pm 2.7$ & $0.49 \pm 0.34$ \\
Range & $24.0-48.7$ & $6.2-39.7$ & $11.8-19.4$ & $0.07-1.12$ \\
\hline
\end{tabular}

where it was first reported on L. santolla.

Miranda-Vargas \& Roccataliata (2004) did not provide data on the prevalence on L. santolla; to our knowledge, the prevalence presently reported is the first for this hostparasite pair. Roccatagliata \& Lovrich (1999) reported that the prevalence of infestations by $P$. tuberculata on $P$. granulosa, decreased with crab size, from $45.6 \%$ at 10 to $20 \mathrm{~mm} \mathrm{CL}$ to $0 \%$ at 90 to $100 \mathrm{~mm}$ CL. High infestation levels were found in $L$. santolla juveniles at the study site in the present work (27.9\% in females and $21.4 \%$ in males). Parasite prevalence was high considering the low number of juveniles analysed. Prevalence values of this study are high when compared with infestation levels reported by González \& Acuña (2004) for the galatheid crustaceans Cervimunida johni and Pleuroncodes monodon off the northern coast of Chile, which varied between $6.8 \%$ and $13.6 \%$ for the former species and between 0.6 to $18.2 \%$ for the latter, based on 1460 and 1677 specimens analysed, respectively.

As mentioned by Roccatagliata \& Lovrich (1999), most branchial bopyrids occur nearly equally in the right and left side of the branchial chamber. There are, however, species that occur only or exclusively in one side. These all belong to the primitive Pseudioninae, and most are parasites of hermit crabs. However, reasons explaining this situation are still unknown. Preference of $P$. tuberculata to occur on the left branchial chamber of their hosts, has been reported for $P$. granulosa (99.6\%) as well as for L. santolla (100\%) sampled at the Beagle Channel (Miranda-Vargas \& Roccatagliata 2004). In our study, $P$. tuberculata occupied left branchial chambers in $98.1 \%$ of the L. santolla specimens analysed, confirming this preference suggested by previous works.
There is much information showing that bopyrids can reduce or even completely stop growth of the host (Petriella \& Boschi 1997). Bopyrid isopods can affect the reproduction of their definitive hosts by partially or totally inhibiting gonad development, modifying secondary sexual characters in males, inhibiting growth, and producing nutritional deficiency in their hosts (Reinhard 1956, Beck 1980, Van Wyk 1982, McDermott 1991, Muñoz \& George-Nascimento 1999, Astete-Espinoza \& Cáceres 2000). In other cases it has been suggested that hosts grow faster because of parasite-induced hunger, eating more food than unparasitized individuals (Choi et al. 2004). Information available about the effect of presence and prevalence of parasites in crustacean decapods in South America is still lacking in the literature. Roccatagliata \& Lovrich (1999) suggested that the reproductive potential of the population of Paralomis granulosa is not seriously affected by the sterilizing effect of $P$. tuberculata. Nevertheless effects of P. tuberculata have not been tested empirically.

Crabs without parasites reached larger body length and weight (Fig. 4) than those parasitized. There are three posible explanations for these results, 1) parasitized crabs grow less than the non-parasitized hosts because of the nutritional demands that the parasite has (Astete-Espinoza \& Cáceres 2000), 2) parasitized crabs died earlier than those non-parasitized, or 3) crabs over $50 \mathrm{~mm}$ length were never parasitized by bopyrid isopods. According to Muñoz \& George-Nascimento (1999) these isopods used to reach young hosts only, so large and non-parasitized hosts were never parasitized by isopods. This suggests that $P$. tuberculata may have an important role in population control of juvenile king crabs. 
All parasites were mature females, each typically carrying a small male specimen attached to the abdomen. The length of the female isopods and that of their host were positively correlated, suggesting that the parasites infest $L$. santolla early in the life of the host, and persist in and grow along with the host throughout life.

Several authors have suggested different explanations concerning the relationship of prevalence of infestation and host size. Rousset et al. (1996) suggested that a decrease in the parasitic load or its dispersion with host age can be considered as evidence of host mortality induced by the parasite. According to González \& Acuña (2004), the strong decrease of bopyrid prevalence in larger sizes of the host could be a consequence of host mortality induced by the parasite or by growth inhibition of the host. However, they also suggested that the parasite could be lost after several ecdyses. Roccatagliata \& Lovrich (1999) reported that the prevalence of the parasite $P$. tuberculata in the Beagle Channel decreased with increasing size in Paralomis granulosa, suggesting a high mortality rate for small parasitized crabs. Nevertheless, they suggested that the absence of $P$. tuberculata in larger sizes ( $<60 \mathrm{~mm} \mathrm{CL}$ ) could be explained by the shorter lifespan of the parasite, assuming a longevity of about eight years in the range of size between 20 to $60 \mathrm{~mm}$ CL. This is probably the same situation in juveniles of L. santolla, supported by the high infestation values up to a determinate size ( $\sim 50 \mathrm{~mm} \mathrm{CL}$ ), as observed in this study, although more research is required to clarify this situation in the future.

During this study, the water column was nearly homogeneous from surface to bottom. The variation in salinity was from 29 to 30.64 psu, temperature varied from 6.5 to $6.6^{\circ} \mathrm{C}$, and density from 23.5 to $24.0 \mathrm{~s}$ units in both sampled sites and in both years. These values were typical in this area of the Magellan Strait (Panella et al. 1991, Antezana 1999, Valdenegro \& Silva 2003). According to Silva et al. $(1995,1998)$ and Sievers et al. (2002), Magellan Strait waters with a salinity of less than $32 \mathrm{psu}$ is a typical estuarine condition. Slight seasonal variations in the salinity of seawater in the embayment studied could promote larval retention and recruitment to the benthos for Lithodes santolla as well as other local benthic invertebrates (Strathmann 1982, Levin 1983). Kelp beds provide important habitats for a variety of marine organisms as well as, contribute to wave damping, which affects local hydrodynamic conditions, providing protection from water motion (Ekman et al. 1989, Balch \& Scheibling 2000). These effects could increase the retention of larval stages of parasitic isopods as it has been postulated for other larval stages of invertebrates as well as for detritus and organic matter (Eckman et al. 1989; Duggins et al. 1990, Pakhomov et al. 2002). One or more of these characteristics of kelp beds may help to explain the high levels of infestation of $P$. tuberculata on L. santolla recruits that settle in kelp beds. Also, because

Table 2

Comparison of the prevalence of the bopyrid isopod Pseudione tuberculata in two species of lithodids (Paralomis granulosa and Lithodes santolla) from two locations at the southern tip of South America

Comparación de la frecuencia de infestación del isópodo bopírido Pseudione tuberculata en dos especies de litódidos (Paralomis granulosa y Lithodes santolla) para dos lugares en el extremo sur de Sudamérica

\begin{tabular}{ccc}
\hline & \multicolumn{2}{c}{ Lithodid species } \\
& $\begin{array}{c}\text { Paralomis granulosa (Beagle } \\
\text { Channel, Argentina) }\end{array}$ & $\begin{array}{c}\text { Lithodes santolla (Magellan } \\
\text { Strait, Chile) }\end{array}$ \\
\hline Host size (mm CL) & Prevalence & Prevalence \\
$<10$ & 0 & not caught \\
10 to 20 & 45.6 & 65 \\
20 to 30 & 35.0 & 22 \\
40 to 50 & 8.7 & $\leq 2$ \\
90 to 100 & $<1$ & not caught \\
General & not indicated & $28($ ( $)$ to $21.5\left(\delta^{7}\right)$ \\
Side of carapace infested & Left & Left \\
Size range of host (mm) & 10 to 100 & 23 to 52 \\
Reference & Roccatagliata \& Lovrich (1999) & This study \\
\hline
\end{tabular}


sites studied were shallow with homogeneously oceanographic features in the water column, larval retention, Pseudione survival, and infestation rates may be higher in the present study because of the homogenous water column as opposed to sites in stratified areas (Sulkin et al. 1980, Roegner 2000). Recently, Cárdenas et al. (2007) described the aggregate behavior, known as podding, of juvenile $L$. santolla at the same area studied here. Aggregations of organisms could explain high parasite prevalence due to the local abundance of hosts available. This podding may explain why there was a higher level of parasitism in this study in comparison with other species (without presence of this aggregation behaviour) infested by Pseudione in other parts of Chile. Nevertheless, this situation should be clarified in future studies.

The presence of $P$. tuberculata infesting $L$. santolla and $P$. granulosa contradicts the assumed degree of host specificity by bopyrids and the apparently restricted distributions of bopyrid parasites relative to those of their host, as suggested by Kazmi \& Boyko (2005) based on their preliminary data. An important conclusion of the present study is that the parasite responds in a similar way in both Lithodes santolla and Paralomis granulosa, independently of the location in the southern end of South America. Thus, high prevalence of $P$. tuberculata is found in crabs of 10-20 mm CL in both crustaceans and remains near to 40-50 mm (Table 2). Differences in the percentage of infestation could be because of the differences in sampling methods. Argentinean researchers used information based on fishery activities (Roccatagliata \& Lovrich 1999). However, in our study, we targeted mainly the smallest individuals found in shallow water. In the future, more studies will be needed to clarify the relationship of prevalence of infestation and host size.

Finally, we propose that the study area is a good experimental site for research on ecological recruitment and the effects of parasitism in Lithodes santolla. For over two years we have been able to predict the months (winter) when the king crab recruits begin to colonize shallow waters, which coincides with periods of higher flux of freshwater discharged by the San Juan River. Future studies are required to clarify any relationship between increase in freshwater discharge and the presence of $L$. santolla recruits and infestations of $P$. tuberculata.

\section{Acknowledgments}

We are grateful to Gustavo A. Lovrich (CADIC, Ushuaia, Argentina) for supplying us with literature on Pseudione and others parasites associated to South American king crabs. We also thank Dr. Daniel Roccatagliata
(Universidad of Buenos Aires, Argentina) for confirming the identity of Pseudione tuberculata specimens. We thank the revision and important comments of two anonymous referees. The biological material was collected in surveys funded by the Dirección de Investigación, Universidad de Magallanes, Chile (Grant PR-F2-03RN-05).

\section{Literature cited}

Anderson G. 1990. Post-infection mortality of Palaemonetes spp. (Decapoda: Palaemonidae) following experimental exposure to the bopyrid isopod Probopyrus pandalicola (Packard) (Isopoda: Epicaridea). Journal of Crustacean Biology 10: 284-292.

Antezana T. 1999. Hydrographic features of Magellan and Fuegian inland passages and adjacent Subantarctic waters. Scientia Marina 69(Suppl. 1): 23-34.

Astete-Espinoza LP \& CW Caceres. 2000. Efecto del parasitismo del isópodo bopírido Ionella agassizi (Isopoda: Epicaridea) (Bornnier, 1900) sobre la fisiología nutricional del nape Neotrypaea uncinata (M. Edwards, 1837) (Decapoda: Thalassinidea). Revista Chilena de Historia Natural 73(2): 243-252.

Balch T \& RE Scheibling. 2000. Temporal and spatial variability in settlement and recruitment of echinoderms in kelp beds and barrens in Nova Scotia. Marine Ecology Progress Series 205: 139-154.

Beck JT. 1980. Life history relationships between the bopyrid isopod Probopyrus pandalicola and one of its freshwater shrimp hosts Palaemonetes paludosus. American Midland Naturalist 104(1): 135-154.

Campodónico I, L Guzmán \& A Sanhueza. 1974. Madurez sexual en los machos de centolla Lithodes antarctica Jacquinot, del área Punta Arenas-Porvenir, estrecho de Magallanes. Anales del Instituto de la Patagonia 5(1-2): 215-222.

Cárdenas CA, JI Cañete, S Oyarzún \& A Mansilla. 2007. Podding of juvenile king crab Lithodes santolla (Molina, 1782) (Crustacea) in association with holdfasts of Macrocystis pyrifera (Linnaeus) C. Agardh, 1820. Investigaciones Marinas 35(1): 105-110.

Choi JH, G Jamieson, KH Han \& SY Hung. 2004. Parapenaeon consolidatum (Isopoda: Bopyridae) and the relative growth and reproduction of Metapenaeopsis dalei (Decapoda: Penaeidae) in South Korea. Journal of Shellfish Research 23(1): 237-242.

Dall W, BJ Hill, PC Rothlisberg \& DJ Sharples. 1990. The biology of Penaeidae. In: Blaxter JHS \& AJ Southward (eds), Advances in marine biology 27: 1-489. Academic Press, London. 
Duggins DO, JE Eckman \& AT Sewell. 1990. Ecology of understory kelp enviroments. 2. Effects of kelp on recruitment of benthic invertebrates. Journal of Experimental Marine Biology and Ecology 143: 27-45.

Eckman JE, DO Duggins \& AT Sewell. 1989. Ecology of understory kelp enviroments. 1. Effects of kelp on flow and particle transport near the bottom. Journal of Experimental Marine Biology and Ecology 129: 173-187.

González MT \& E Acuña. 2004. Infestation of Pseudione humboldtensis (Bopyridae) in the squat lobsters Cervimunida johni and Pleuroncodes monodon (Galatheidae) off northern Chile. Journal of Crustacean Biology 24: 618-624.

Kazmi QB \& CB Boyko. 2005. A new locality and host for Pseudione minimocrenulata Nierstrasz \& Brender à Brandis, 1931 (Crustacea Isopoda: Bopyridae) in the Indian Ocean, with comments on the identity of the type specimens. Zootaxa 925: 1-10.

Levin L. 1983. Drift tube studies of bay-ocean waters exchange and implications for larval dispersal. Estuaries 6: 364-371.

Lovrich GA. 1997. La pesquería mixta de las centollas Lithodes santolla y Paralomis granulosa (Anomura: Lithodidae) en Tierra del Fuego, Argentina. Investigaciones Marinas 25: 41-57.

Lovrich GA. 1991. Reproducción y crecimiento del centollón, Paralomis granulosa (Crustacea, Anomura, Lithodidae) en el Canal Beagle. Tesis de doctorado, Facultad de Ciencias Exactas y Naturales, Universidad de Buenos Aires, Buenos Aires, 160 pp.

Lovrich GA \& JH Vinuesa. 1995. Growth of juvenile false southern king crab Paralomis granulosa (Anomura, Lithodidae) in the Beagle Channel, Argentina. Scientia Marina 59(1): 87-94.

Lovrich GA, D Roccatagliata \& L Peresan. 2004. Hyperparasitism of the cryptoniscid isopod Liriopsis pygmaea on the lithodid Paralomis granulosa from the Beagle Channel, Argentina. Diseases of Aquatic Organisms 58: 71-77.

McDermott JJ. 1991. Incidence and host-parasite relationship of infection (Crustacea, Isopoda, Bopyridae) in the Brachyuran crab Pachygrapsus transversus from Bermuda. Ophelia 33: 71-95.

Miranda-Vargas P \& D Roccatagliata. 2004. A redescription and new host record for the parasitic isopod Pseudione tuberculata (Epicaridia: Bopyridae) from the Beagle Channel, Argentina. Cahiers de Biologie Marine 45: 157166.

Muñoz GI \& M George-Nascimento. 1999. Comparaciones de los efectos recíprocos en la simbiosis entre camarones fantasmas (Decapoda: Thalassinidea) e isopodos bopíridos
(Isopoda: Epicaridea). Revista Chilena de Historia Natural 72: 49-58.

Pakhomov EA, S Kaehler \& CD McQuaid. 2002. Zooplankton community structure in the kelp beds of the sub-Antarctic Prince Edward Archipelago: are they a refuge for larval stages? Polar Biology 25: 778-788.

Panella S, A Michelato, R Perdicaro, G Magazzù, F Decembrini \& P Scarazzato. 1991. A preliminary contribution to understanding the hydrological characteristics of the Strait of Magellan: Austral Spring 1989. Bollettino di Oceanologia Teorica ed Applicata 23(9): 107-126.

Pardo LM, C Guisado \& E Acuña. 1998. Pseudione humboldtensis, a new species (Isopoda, Bopyridae) of parasite of Cervimunida johni and Pleuroncodes monodon (Anomura: Galatheidae) from the northern coast of Chile. Proceedings of the Biological Society of Washington 111: 272-277.

Petriella AM \& EE Boschi. 1997. Growth of decapod crustaceans: results of research made on Argentine species. Investigaciones Marinas 25: 135-157.

Reinhard EG. 1956. Parasitic castration of Crustacea. Experimental Parasitology 5: 79-107.

Richardson H. 1904. Contributions to the natural history of the Isopoda. Proceedings of the United States National Museum 27: 1-89.

Roccatagliata D \& GA Lovrich. 1999. Infestation of the false king crab Paralomis granulosa by Pseudione tuberculata (Isopoda: Bopyridae) in the Beagle Channel, Argentina. Journal of Crustacean Biology 19: 720-729.

Roegner GC. 2000. Transport of molluscan larvae through a shallow estuary. Journal of Plankton Research 22: 17791800.

Román-Contreras R \& I Wehrtmann. 1997. A new species of bopyrid isopod, Pseudione chiloensis, a parasite of Nauticaris magellanica (A. Milne-Edwards, 1891) (Crustacea: Decapoda: Hippolytidae). Proceedings of the Biological Society of Washington 110: 242-248.

Rousset F, F Thomas, T de Meeûs \& F Renaud. 1996. Inference of parasite-induced host mortality from distributions of parasite loads. Ecology 77: 2203-2211.

Sievers H, C Calvete \& N Silva. 2002. Distribución de características físicas, masas de agua y circulación general para algunos canales australes entre el golfo de Penas y el estrecho de Magallanes (Crucero Cimar Fiordo 2), Chile. Ciencia y Tecnología del Mar 25: 17-43.

Silva N, H Sievers \& R Prado. 1995. Características oceanográficas y una proposición de circulación, para algunos canales australes de Chile, entre $41^{\circ} 20^{\prime} \mathrm{S}$ y $46^{\circ} 40^{\prime} \mathrm{S}$. Revista de Biología Marina 30: 207-254. 
Silva N, C Calvete \& H Sievers. 1998. Masas de aguas y circulación general para algunos canales australes entre Puerto Montt y laguna San Rafael (Crucero Cimar Fiordo 1). Ciencia y Tecnología del Mar 21: 17-48.

Strathmann RR. 1982. Selection for retention or export of larvae in estuaries. In: Kennedy VS (ed), Estuarine Comparisons; pp. 521-536. Academic Press, New York.

Stuardo J, R Vega \& I Céspedes. 1986. New bopyrid isopod parasitic on Callianassa uncinata $\mathrm{H}$. Milne-Edwards: with functional and ecological remarks. Gayana 50: 3-15.

Sulkin SD, W van Heukelem, P Kelly \& I van Heukelem. 1980. The behavioural basis of larval recruitment in the crab Callinectes sapidus Rathbun: a laboratory investigation of ontogenetic changes in geotaxis and barokinesis. The Biological Bulletin 159: 402-417.

Tapella F \& G Lovrich. 2006. Asentamiento de estadios tempranos de las centollas Lithodes santolla y Paralomis granulosa (Decapoda: Lithodidae) en colectores artificiales pasivos en el Canal Beagle, Argentina. Investigaciones Marinas 34(2): 47-55.
Thatje S. 2003. Review of the Thalassinidea (Crustacea: Decapoda) from Chile and Argentina. Anales del Instituto de la Patagonia 31: 115-122.

Valdenegro A \& N Silva. 2003. Caracterización oceanográfica física y química de la zona de canales y fiordos australes de Chile entre el estrecho de Magallanes y cabo de Hornos (Cimar 3 Fiordos). Ciencia y Tecnología del Mar 26: 1961.

Van Wyk PM. 1982. Inhibition of the growth and reproduction of the porcellanid crab Pachycheles rudis by the bopyrid isopod, Aprorobopyrus muguensis. Parasitology 85: 459473.

Vinuesa JH. 1989. Efectos e incidencia del parasitismo en la centolla (Lithodes santolla) y el centollón (Paralomis granulosa) del Canal de Beagle. Physis (A) 47: 45-51.

Zar JH. 1999. Biostatistical Analysis, 663 pp. Prentice-Hall, Englewood Cliffs.

Recibido el 8 de enero de 2008 y aceptado el 21 de abril de 2008 